Historic, Archive Document

Do not assume content reflects current scientific knowledge, policies, or practices. 



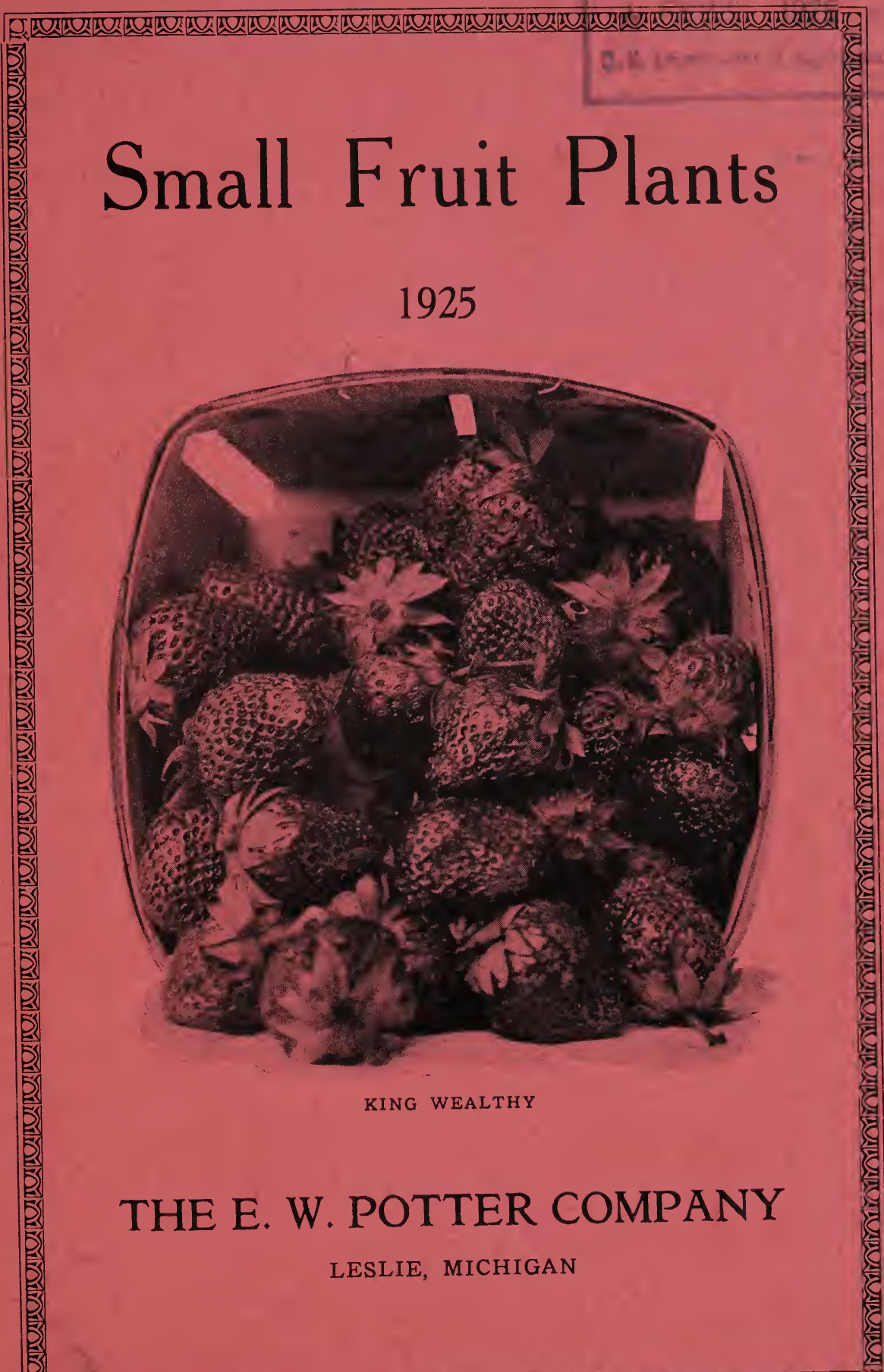

20 


\section{King Wealthy}

July $24,192 t$.

The E. W. Potter Co.,

Lesiie, Michigan.

Dear Sir :

We are writing you to tell you of our approval and recommend for the great King Wealthy Strawberry. We do not do this on one year crop; we have repeated and know whereof we speak. We only have a small piece about one-sixth of an acre and we picked 1700 boxes at the rate of 10,200 boxes to the acre. This is the second crop, the first crop was not quite as good. We are cleaning them out for the third crop. We are picking table berries yet. My neighbor was picking some for a shortcake yesterday and he asked me if those King Wealthy Strawberries were not everbearing?

The plants I got from you this spring and the ones $I$ set out from my own patch are all doing fine and next year I will have a larger harvest.

Two years ago I set out some Red and Black Raspberries, also Blackberries. My fruit business is only a side-line, strictly for pleasure as I do not golf, hunt, fish or pool, but do like garden and shrubs and nature. I hire a large part of the work done and pay good prices for labor and then have a good profit. So I say that the right man, if he likes to work, can make a splendid income from a small fruit farm. And why doesn't every-

body that has a home have a garden and small truit?

Thanking you and wishing you all success, I am,

Yours very truly,

D. D. SHANE,

Eaton County, Michigan.

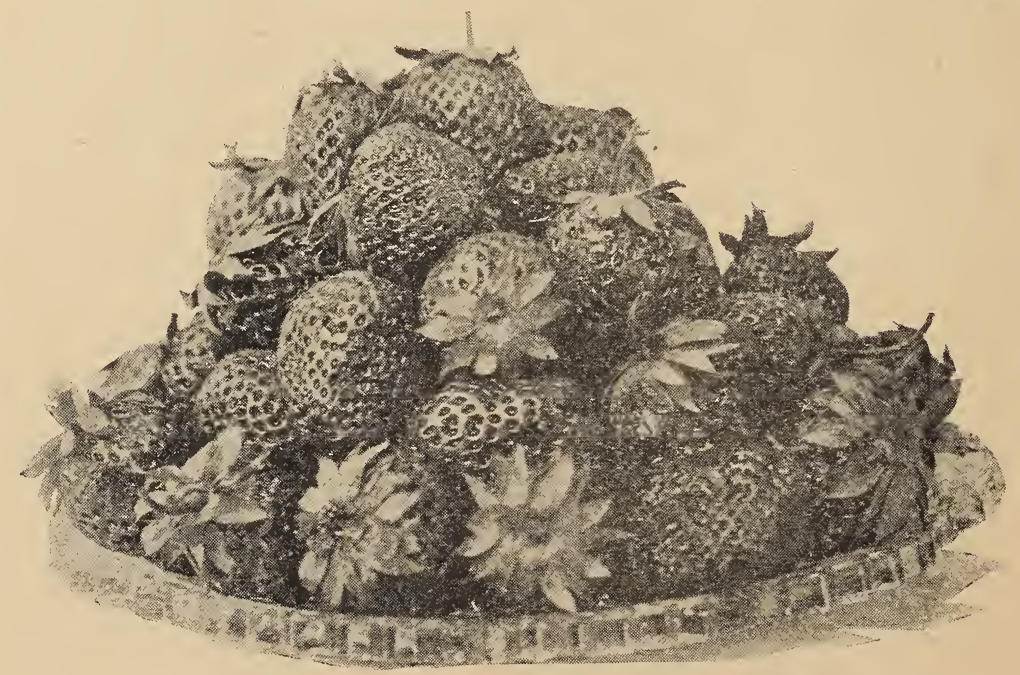

KING WEALTHY, THE MONEY-MAKER 


\section{A NEW YEAR}

We believe this will be a record-breaking year for every one that tills the soil for a living. Especially do we think so for the fruit grower. To those of you who have never experienced the pleasure of a strawberry bed where you could pick fresh, juicy, sweet stranberries for your table every day during the berry season and have plenty to can, preserve and jelly for winter use, we urge you, TO PLANT A STRAWBERRY BED.

The time, expense and space required to grow all the strawberries your family can possibly use is insignificant compared with the pleasure and profits to be gained. Fen people realize the big expense of having to buy all the strawbervies needed for their tables, while at the same time they do not realize how cheaply this same amount and many more berries can be grown. The pleasure of having all the strawberries your family can use is yours by setting a few stranberry plants this spring; but, just as sure as you do not grow your own stranberries, you will never have all you actually need.

The idea that a good many have about raising small fruit is that special location as regards soil, lay of the ground, and extra work and cultivation must be had, in order to get the required results. Any one that understands the preparation of soils for the different farm. crops and how to properly cultivate them can grow small fruit. So much is written now-a-days in our various agricultural papers on the care and cultivation of small fruits that there should not be any trouble for one to care for the small plot of ground devoted to fruit for home use. Good varieties properly set out, given clean and thorough cultivation and winter protection, is about all there is to it.

This catalog tells the truth as regards to every description given and every testimonial that is printed, together with hundreds of others just as good, are on file in our office. We are presenting to you dependable facts, worthy of your consideration.

We invite your patronage in the belief and confidence that we can give you a thoroughly satisfactory service.

We are ready for your order right now and riqht now you should send it so you nill be assured of getting just the varieties you want and at just the time you want them.

Sincerely yours,

The E. W. Potter Company. 


\section{Strawberries We Grow}

ABINGTON (Per.)

We have fruited Abington for years and find it a strong grower, with large, luxuriant foliage. The fruit is large, quite similar in size and shape and color to Sharpless, but more abundant. (Mid-season.)

\section{AROMA (Per.)}

One of the most popular late varieties. A good plant and a good bearer of large, handsome fruit bright red in color; uniform roundish heart shape; firm and of good quality. Somewhat resembles Gandy in appearance. A choice variety and reliable.

\section{AUGUST LUTHER (Per.)}

A good grower and reliable. Fruit large, glossy bright red, firm, and of good quality. This berry comes early, always making a good crop before berries lower wuch in price, and for several years has been our choice for early market among the Standards.

\section{BUBACH (Imp.)}

Fruit large, moderately firm, good color and quality well known standard variety productive and reliable. Mid-season. We are nearly always sold out of this variety before the season is over.

\section{BILLY SUNDAY (Per.)}

Plants purchased from the originator, Mr. Yost of Ohio. Plants very healthy, tall, dark green foliage long, heavy fruit stalks making berries easily gathered. The fruit is very large, glossy red, slightly wedge shaped, uniform in shape and size. It has a delicious flavor, firm and a good shipper. Ripens about the same season as Haverland.

\section{BEDERWOOD (Per.)}

Well known standard early market variety. A tough, healthy grower. Very successful, especially in the west prairie country. Fruit medium to large size round, bright red, good quality. A good carrier and very productive.

\section{BRANDYWINE (Per.)}

Fruit large, dark red, quite firm, good quality. Not always at its best in some sections, but a good variety in others; requiring strong loam soil and high culture for best results. Medium late.

\section{CAMERON'S EARLY (Per.)}

Extra early. This fruit is of good size for so early a berry; medium red in color and of good quality. A vigorous grower, with a tall foliage to protect the bloom from late frosts. Productive and reliable.

\section{CLYDE (Per.)}

Very productive. Fruit large, round, bright glossy red. Large, healthy plants. Well known standard market variety. Mid-season.

\section{CAMPBELL'S EARLY (Per.)}

Fruited here for the first time under favorable conditions. Showed up better than even we expected. It fruited very early, producing a good crop of large bright red berries. Worthy of trial.

\section{COOPER (Per.)}

Mid-season. After fruiting this variety we can say it came up to our expectations. The plants are strong growers and very productive. The fruit is large, beautiful in color and has a delicious flavor.

\section{COMMONWEALTH (Per.)}

Very late. James Munroe (the introducer) in his description says the Commonwealth is the outcome of the desire and effort to produce a berry that would lengthen the strawberry season. In it we have a berry that is as large as the largest, as productive as any, has fine flavor, as solid, and as dark a color as any. The plant is a strong grower, but not so rank as some. The fruit is large, firm, dark color and very handsome. Judging from the orders we have received for these p'ants our customers are beginning to realize what a valuable variety this is for late fancy fruit. Later than Gandy.

\section{CORSICAN (Per.)}

This is a favorite variety especially around Rochester, N. Y. The plants are large and good growers. Fruit large, longish heart shape, good quality; stands shipment well. Mid-season. Very similar in plant and fruit to Uncle Jim. A good variety.

\section{CHESAPEAKE (Per.)}

This is comparatively a new variety. If it was a better plant maker it would be the leading late berry, for it has them all beat for size, productiveness and quality. We have tried it on all kinds of soil, but fail to get a good plant row. We hear similar results from other sections. The berry is large and regular in shape; color bright red. Quality much better than Gandy.

\section{COLLINS (Per.)}

Introduced by a western Michigan fruit grower who claims it is his best cropper. With us it made a good fruit row, produced some good fruit, but no better than other varieties of a similar nature.

This variety stands among the very best in the mid-season strawberries. Several dealers say as good as Dunlap or better. It resembles Dunlap in many ways. It is exceedingly productive, of medium to large, well shaped, glossy red. Through and through we have yet to hear a poor report on Dr. Burrill. 


\section{EXCELSIOR (Per.)}

The well known standard early market variety. Plants vigorous, making many runners. Fruit medium to large size; round; dark red; firm; quite tart. Reliable and productive.

\section{EARLY OZARK (Per.)}

Early. The introducer of this berry says it is a cross between Excelsior and Aroma. He further states that it is a perfect bloomer and has very large blossoms that are rich with pollen. It is the largest extreme early variety I have ever tested. The plants grow strong and are healthy. The fruit is firm, excellent flavor and good color, being bright red, about the same as the Aroma. It is said to be very productive. The fruit is large, good color, and firm.

\section{GANDY (Per.)}

Fruit large, firm, high quality and handsome. A good grower and productive. The well known standard late shipping berry.

\section{GLEN MARY (Imp.)}

Fruit large, dark red, quite firm and good quality. A good grower, productive and reliable. This variety has small stamens, sufficient for itself, but not to retilize adjoining pistillates, and so we class it as an imperfect bloom. Mid-season to late.

\section{GIBSON (Per.)}

This is not the old variety of that name which originated in eastern New York several years ago, but a distinct variety of local fame. The berry is large and regular in shape, holding its size well to the end of the season. Color rich red. Flavor is neither too sweet nor too sour, but just right for canning. It makes a good plant row and is worthy of trial.

\section{HERITAGE (Per.)}

Mid-season. After fruiting this variety another season we can say that it came up to our expectations. The plant grows very large with extremely heavy crown. The fruit is large and handsome. The berry is quite dark, shiny crimson. It is quite a favorite in some sections.

\section{HOWARD No. 17 (Per.)}

Fruited here for the first time. Produced good sized fruit of fair quality. Large, stocky plants, making a good fruit row. iVorthy of trial.

\section{HAVERLAND (Imp.)}

Very productive. Large fruit, rather long; bright light red; firm, good quality. Plants large and vigorous. Well known standard variety and reliable. Season early to late.

\section{KING WEALTHY (Per.)}

Very late. A new variety. Our introduction. Makes good fruit row. Has a strong staminate blossom, fruit large, handsome, well shaped, and dark red. Fine for canning. Worthy ot trial.

\section{KELLOGG'S PRIZE (Imp.)}

This Pistillate variety is claimed to cover a long season. After giving it a good trial we find it to be a variety of great merit. It was one of the best varieties we fruited the past season. The plants are strong growers and very productive. The fruit is high color, fine flavor and very large. Quite late.

\section{LUPTON (Per.)}

We received our plants from a well known grower who claims it is a very large, attractive berry. We are not going to say much for or against this variety until it has been thoroughly tested. From what we can learn we believe it is going to be one of the leading varieties. We understand that it ripens about the same season as Chesapeake. Made a fairly goad fruiting row for us.

\section{LATE JERSEY GIANT (Per.)}

New. Claimed to be late as Gandy, but better. With us it is a poor plant maker, but produced some large, fancy fruit. Quite late.

\section{MARSHALL (Per.)}

A standard of quality. Very dark red; heart shape, firm and of high quality. A moderate plant maker of large, stocky plants.

\section{PARSON'S BEAUTY (Per.)}

A good healthy grower and an immense cropper of large, solid, dark red berries of good form and quality. There is probably not a variety among the standards that will outyield it, or a more reliable. A first-class variety, with a long season.

\section{PENNELL (Per.)}

Fruit large, nearly round; dark, rich color; firm and of the very highest quality. We think more of the Pennell every year. It always bears abundantly, and is one of the varieties to which we direct friends who visit us at fruiting, who want something extra fine. Grow Pennell on strong loam and be surprised with the large size and excellence of this berry. An all-season variety.

\section{PRIDE OF MICHIGAN (Per.)}

Mid-season. From Mr. Baldwin of Bridgman. There seem to be two varieties by this name, but as the Kellogg strain is similar if not identical with New York, which was discarded by us some time ago, we will only offer the Baldwin strain. The berries are large, rather oblong, very bright red, glossy, and beautiful; it being very firm, makes it an excellent shipping berry. The plant is vigorous, making a good fruiting row in any kind of season. 


\section{PREMIER (Per.)}

An early variety, being large, of extra good quality, and color being fine, which makes it a good shipping berry. We consider this one of the larger of the earlier varieties. The berries are firm and beautiful in form and have few weak points. Has extra long season and is worthy of trial.

\section{ST. LOUIS (Per.)}

While some claim this variety is a second early, we find it extra early and one of the first to ripen. We have been highly pleased with it for some time and can recommend it as Oueen of the Earlies. This berry is not firm enough for long shipping, but as it has so many good points every grower should plant some. Mr. Bauer, the introducer, claims to have grown them so large that twelve of them would fill a quart basket. As grown here, it makes a strong, healthy plant, with plenty of runners. Fruit very large for such an early berry. light red color, nearly round and good quality.

\section{STEVENS LATE CHAMPION (Per.)}

A variety that is a splendid, healthy grower, with tall, dark green foliage and long runners. The fruit is large and fine, resembling. Gandy. Firm and of good quality, outyielding Gandy here last year and selling at the highest prices. It is certainly a good variety.

\section{SAMPLE (Imp.)}

Standard market variety. Mid-season to late. Fruit large, roundish conical; bright glossy red; moderately firm and of good quality. A good grower. Productive and reliable.

\section{SENATOR DUNLAP (Per.)}

This variety has given general satisfaction in almost all sections and all kinds of soil, and the demand for plants increases each season. It makes plants of only medium size but tough and hardy, with long roots and a surprising capacity for enduring hardships. It is very productive and usually matures every berry. They are of good size, bright glossy red, and of excellent quality. It is a first-class shipper, and retains its brightness after being picked. It ripens early and continues a long time in fruit. It is grown largely as a commercial berry.

\section{UNCLE JIM (Per.)}

Ever since we introduced this variety we have given the history and a long description of it. Since it is so well known we feel it useless to write so much. For the benefit of those who receive this catalog for the first time we give the following description: This variety is an excellent grower of large, stocky plants. The roots grow down deep in the soil, making it very popular in sections with limited rainfall. The fruit is very large, high colored and of excellent quality. It is famous for its delicate, rich, sub-acid flavor which makes it possible for the most confirmed dyspeptic to enjoy. We can recommend this variety to those looking for large, fancy fruit.

-

WARFIELD (Imp.)

The well known standard shipping and canning berry. Plants are vigorous and productive. Fruit large, nearly round, dark glossy red, firm and of good quality. Mid-season. This and Dunlap make a good, strong team.

\section{WM. BELT (Per.)}

This variety is large planted in some sections, while in others it is inclined to rust. It is a fancy variety that always brings fancy prices. It is quite productive, berries very large, roundish conical, color a bright glossy red, and the flavor good. Mid-season.

The E. W. Potter Co., Leslie, Michigan.

May 6th, 1924 .

Dear Sir: Enclosed find my order for 1,000 Parson's Beauty. I received some of same two years ago; they bore me the most and largest berries of any variety I have raised and I have had several kinds.

Yours,

\section{E. W. VAN AVERY, \\ Emmet County, Michigan.}

The E. W. Potter Co.. Leslie, Michigan.

June 9 th, 1924.

Dear Sir: Many thanks for the extras, just the variety we would like to try out. Our plants are doing nicely, did not lose more than one or two. Would have taken the amount of stamps you returned in plants if we had known there would be any.

Yours,

F. F. DYER, Eaton County, Michigan. 


\section{GARDEN COMBINATION OFFER}

No. 1

50 COOPER

50 KING WEALTHY

50 DR. BURRILL

$\$ 1.00$

50 AUGUST LUTHER

No. 2

100 DUNLAP

100 KING WEALTHY

100 BEDERWOOD

$\$ 2.50$

100 GIBSON

100 PREMIER

25 plants FREE, any variety in catalog

No. 3

200 DUNLAP

200 KING WEALTHY

200 PREMIER

200 LUPTON

$\$ 5.00$

200 KELLOGG'S PRIZE

25 plants $\mathrm{FREE}$, any variety in catalog

No. 4

500 DUNLAP

500 KING WEALTHY

500 PREMIER

500 DR. BURRILL

50 plants FREE, any variety in catalog 


\section{Of Importance to Customers}

\section{SUBSTITUTION}

We desire to furnish each customer exactly what he orders, but sometimes find the variety all sold before his order is reached. If marked "no substitution," we are obliged to disappoint our customers by returning money late in the season, although able to supply another sort of like season and of equal if not greater value. In such case, except for new varieties for testing, unless the order is marked "no substitution," we will understand you desire us to use our best judgment for your benefit, and we will, if thus permitted, give extra count or include something new and valuable.

\section{LOST ORDERS}

All orders are acknowledged by postal card same day received, but if you should not hear from us in a reasonable length of time after sending an order, PLEASE WRITE PLAINLY, giving full particulars, NAME AND ADDRESS.

Once in a while an order is lost, but it usually is caused by the customer failing to give the full address. Therefore, PLEASE WRI'TE PLAINLY, especially your name.

\section{SETTING PLANTS IN THE FALL}

We are anxious at all times to please our customers, who in some way fail to get their plants in the spring, by sending them a few in the fall. However, spring is by far the best time to plant strawberries. Spring planting is preferred because weather conditions are more favorable and because the plants come into bearing the next season. Fall set plants have to go through two winters before they start to fruit and the effect of winter is never beneficial to their plantation. To those who are unfortunate and do not obtain their plants in the spring, we will gladly supply their needs at double the price in catalog.

\section{NORTHERN GROWN PLANTS}

A strawberry plant is never in so prime a condition as when fully grown, matured and dormant. Our friends in the South have recognized that our Northern grown plants are safer to set, because of their more dormant condition on arrival, while commercial growers in the North and West would not think of setting Southern stock of a more advanced growth. We also hold that while the strawberry will grow and thrive nearly everywhere, the North is its natural home, where it fits the conditions more naturally for a higher development.

\section{REMOVING THE BLOSSOMS}

Strawberry plants that are set out this spring should not be allowed to bear fruit until the following spring. The blossoms should be pinched off, for to let them ripen fruit the first year would weaken the growth of the plants and is liable to kill them. Just as soon as you remove the blossom your plant starts to work building up a root system. The heavy, vigorous root system is essential to enable the plant to come to its fullest possibilities of production.

\section{NUMBER OF PLANTS REQUIRED TÓ SET AN ACRE}

$\begin{array}{llllll}1 \text { by } 1 \text { foot, } 43,560 & + \text { by } 1 \text { foot, } 10,890 & 5 \text { by } 3 \text { feet, } 2,904 & 6 \text { by } 5 \text { feet, } 1,452 \\ 2 \text { by } 1 \text { foot, } 21,780 & \text { 4 by } 2 \text { feet, } 5,445 & 5 \text { by } 4 \text { feet, } 2,178 & 6 \text { by } 6 \text { feet, } 1,210 \\ 2 \text { by } 2 \text { feet, } 10,890 & 4 \text { by } 3 \text { feet, } 3,630 & 6 \text { by } 1 \text { foot, } 7,160 & \text { i by } 1 \text { foot, } 6,122 \\ 3 \text { by } 1 \text { foot, } 14,520 & 4 \text { by } 4 \text { feet, } 2,722 & 6 \text { by } 2 \text { feet, } 3,360 & \text { i by } 2 \text { feet, } 3,111 \\ 3 \text { by } 2 \text { feet, } 7,260 & \text { 5 by } 1 \text { foot, } 8,712 & 6 \text { by } 3 \text { feet, } 2,420 & 7 \text { by } 3 \text { feet, } 2,074 \\ 3 \text { by } 3 \text { feet, } 4,840 & \text { 5 by } 2 \text { feet, } 4,356 & 6 \text { by } 4 \text { feet, } 1,815 & \text { i by } 4 \text { feet, } 1,555\end{array}$


The E. W. Potter Co., Leslie, Michigan.

May 8 th, 1924 .

Dear Sir: We received the plants in fine shape and we think them the finest looking we ever bought.

Thanks,

JACOB N. DE WITT,

Ingham County, Michigan.

The E. IV. Potter Co., Leslie, Michigan.

April 28th, 19:24. lovely.

Dear Sir: I am enclosing postage on strawberry plants. They were Yours truly,

IIRS. HILLEARY A. MEANS.

McLean County, Michigan.

The E. II. Potter Co., Leslie, Michigan.

April 25th, 1924.

Dear Sir: The plants I received lcok to me to be a first-class lot. E. H. NEWMAN,

Charlevoix County, Michigan.

The E. II. Potter Co., Leslie, Michigan.

April 21st, 19:24.

Dear Sir: Your berry plants arrived all O. K.; they were fine. Very respectiully.

THOS. S. PEARSON.

Audrian County, Missouri.

May 8th, 19:24.

The E. IV. Potter Co., Leslie, Michigan.

Dear Sir: Plants came in fine ccndition. Thanking you and wishing you success, I am,

D. D. SHANE,

Eaton County, Michigan.

May 20 th, 1924.

The E. W. Potter Co., Leslie, Michigan.

Dear Sir: Received the C. O. D. package of strawberry plants and they were in fine shape when received. Yours truly,

The E. IV. Potter Co., Leslie, Michigan.

W. M. PETERSON.

Washburn County, Wisconsin.

May 18th, 1924.

Dear Sir: Strawberry plants in good shape: they are very fine plants. I thank you.

$$
\text { Sincerely, }
$$

FRANK UMBARGER.

Eaton County, Michigan.

The E. II. Potter Co., Leslie, Michigan.

May 19th, 19:2t.

Dear Sir: Please send another one hundred plants; the first one hundred were fine plants. Respectfully,

O. L. PHILLIPS,

Eaton County, Michigan. 


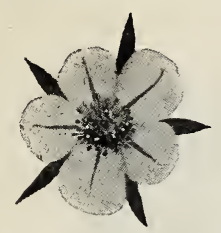

Perfect Blossom

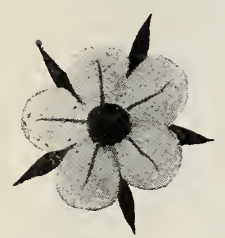

Imperfect Blossom

\section{Strawberry Culture}

\section{MATING}

All strawberry blossoms are either staminate-also called perfect-or pistillate, generally called imperfect.

The imperfect varieties, which are marked ( $\mathrm{mp}$.) in catalog, should have a perfect variety, marked (Per.), set every third or fourth row to properly pollenize the blossoms of the imperfect sorts.

There seems to be a mistaken idea with some that this mixing of varieties is necessary with the perfect as well as the imperfect sorts; but this is not so. The perfect are self-pollenizing, and bear as well if set by
themselves.

Here it is not our purpose to try to tell you all there is to know about growing strawberries. Many books would be too few to hold all that might be written. It is our intention only to give you the outlines; tell you the things you must do, if you do nothing else. For all the rest we must refer to the many most worthy books and magazines which dea? with these matters. Every strawberry grower ought to have a good fruit paper. If we can set you straight at the beginning on the things which are the most important of all we will be happy to have done so. First and foremost though, remember that you must have select, high quality, sturdy plants; these lacking you are all wrong.

\section{SOIL CONDITIONS}

Generally speaking, any soil that will produce a good crop of corn or potatoes will produce a good crop of strawberries. It must be well drained, for it will longest keep the moisture the strawberry plant or any other plant must have. Choose a good length of time. Remember that the strawberry ripens at a time when you may reasonably expect drought. Provide, therefore, far in advance for this very thing. Take lots of pains. Your strawberry crop is of more value than the ordinary farm crop. It will, thereiore, repay more completely any work you put on it. Get the soil in perfect condition; supply it with the necessary plant food.

\section{MANURING THE GROUND}

When the soil is at all deficient in fertility, we would advise using well-rotted stable manure.

If possible, apply it the year previous to setting out the plants and grow some crop that must be thoroughly cultivated or hoed. This will put the soil into the very best possible condition for the strawberry plant.

We would caution against the use of new stable manure, for the reason that it contains so often a great many weed seeds which will cause trouble later.

\section{FITTING THE SOIL}

Have the manure spread; the next step is thorough pulverization of the soil. Plow or spade to an even depth; in shallow soil six inches, in deep soil eight inches is not too much-but break evenly. Crop results depend greatly upon the breaking of the ground; a piece of ground unevenly broken cannot be brought into perfect, ideal condition.

Harrow thoroughly two or three times-do it again if you want to; you can't get it too fine for good results. We generally harrow with the furrows, then diagonally each way. We then follow with a heavy roller. If you have no roller at hand, a plank drag or "float," as we call it, will serve, if heavily weighted. This firming of the ground is very important. It is almost impossib'e to set plants properly if the soil is not reasonably level and firm at the surface. Easy to do all this work at the beginning and it counts all the time your strawberry bed is there.

\section{"MARKING OUT" FOR PLANTS}

Do it any way that will give you a straight, shallow mark to set by. Don't forget that a straight row means easy cultivation by and by. We use a light sled with three runners, one in the middle and one on each side, giving us rows four feet apart. It makes a very satisiactory imp?ement for the purpose.

\section{SETTING THE PLANTS}

Of course, you have been taking good care of them since you got them. If possible set them at once. If packed properly, as all ours are, they will be in first-class condition for setting when you take them out of the moss.

When your ground is thoroughly prepared, smooth as a floor and marked in rows, setting of the plants themselves is a simple operation, but an important one. Do it yourself unless you can find some one who can do it better. A little practice makes the work easy and rapid. Take out plants in a basket or some other convenient carrier; moisten the roots. If the roots are very long they should be cut back two or three inches, depending on the size of the plant. The plant should be held by the upper part of the crown make an opening with a dibble or spade just large enough for the roots, then lower the plant until the crown is even with the surface. Press the soil with your foot firmly to each side of the plant to close the entire opening. Don't leave any airholes to take out all the moisture and dry the roots.

\section{CULTIVATE THE STRAWBERRY BED}

Cultivation should begin soon after the plants are set and repeated at least every eight or ten days. Clean and shallow cultivation is the watchword of the successful strawberry culture. You should cultivate as soon after rains as the ground is fit. The soil condition should always determine the time of cultivation. Don't allow a crust to form, if possible. Weeds are a blessing in disguise - they compel you to cultivate. Don't forget the hoe.

\section{WHEN TO MULCH}

Mulching the plants is one of the most important features to be considered and we cannot lay too much emphasis on this point. In northernly latitudes where freezing and thawing begin early to alternate, as well as in those colder sections where freezing weather comes to stay a while, mulch should be applied soon after the first hard freeze in the fall, but in the South where mulching is done to retain moisture and keep the fruit clean, it need not be done until shortly after the buds open. 
March 30th, 1924.

The E. W. Potter Co.,

Leslie, Michigan.

Dear Sir: Your plants last season were the finest we ever received. If your King Wealthy meets our expectations, and we believe it will, we will want a large shipment next fa!1, at least enough for ten (10) acres. We are the largest growers in the Ozarks.

Respectfully,

EBERLE \& KASTNER,

Benton County, Arkansas.

April 4th, 1924.

The E. W. Potter Co.,

Leslie, Michigan.

Dear Sir: I am hoping that you can supply me with these few King Wealthy plants for the garden as I enjoyed so much the ones I had from you two years ago. If I am too late you may substitute.

\section{Yours,}

EDITH HAMMOND,

Eaton County, Michigan.

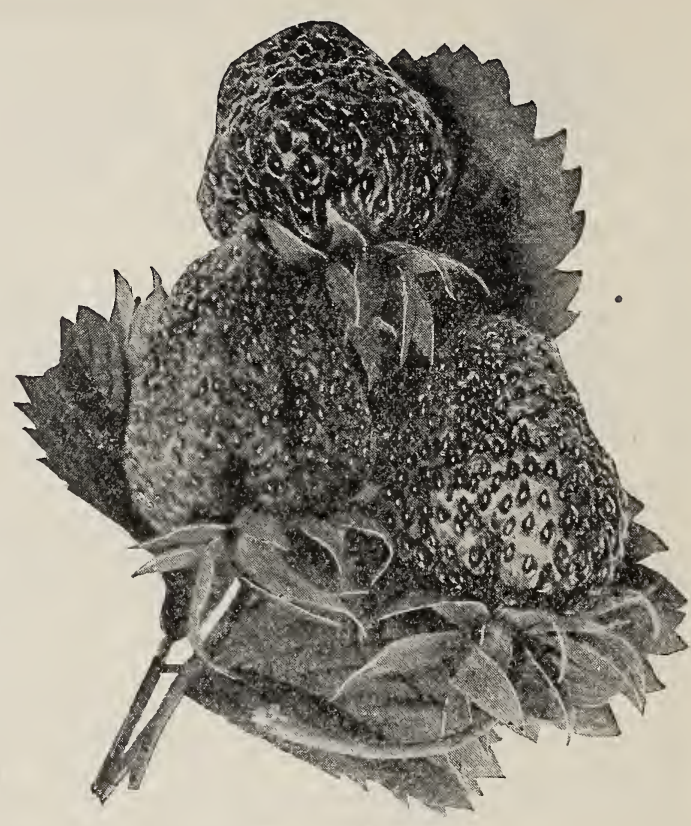

KING WEALTHY

\section{Customers, Please Notice!}

If plants are wanted by parcel post, postage must be added as per table.

\section{IMPORTANT}

In remitting postage, always add it to the foot of the order as a separate item. This will help to avoid mistakes. Your local postmaster will inform you what zone you are in from Leslie, and you can add for postage accordingly.

Plants vary so much in weight, as some varieties make small plants, while others make large, that it is impossible to give you the exact weight.

We have tried to give you an approximate estimate of the weight of different plants.

Packages weighing over 5 pounds going beyond the fifth zone will go cheaper by express.

Do not ask us to ship large orders by parcel post.

Be sure to send enough postage.

Fifty pounds can be shipped in the first and second zones, and twenty pounds to all other zones.

First pound Each

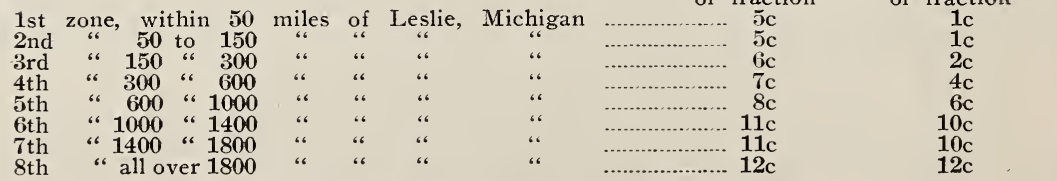

“

ESTIMATED WEIGHT OF PLANTS

50 Strawberry Plants

100

100 Blackberry " "

100 Raspberry " " (Sucker) 


\section{TERMS, ADVICE, ETC.}

Our Shipping Season begins with the southern orders, as soon as frost is out of the ground in spring, often in March. We aim to set out plants in early April. If ordered late in the season, it is always best to name a second or third choice in case a variety is sold out, or leave it with us, stating soil conditions and other particulars. We will do our best to please you, but order early and have plants come early, if you can.

TERMS-Cash with orders, but orders will be booked if one-fourth value is enclosed, the remainder to be sent before shipment. C. O. D. orders require onefourth value with order. Send remittance at our risk by post-office order, express money order, bank draft or registered letter. Stamps taken for parts of a dollar.

Claims, if any, must be made upon receipt of goods so that mistakes, should any have been made, may be promptly corrected. We take great pains to avoid mistakes, but should any error have been made, please notify us of the fact at once.

Canadian Shipments accompanied with invoice, owing to the duty, with charges guaranteed to avoid delay. Please do not send Canadian stamps.

For Our Responsibility address with stamp the People's Bank, Leslie, Mich., postmaster, express agent, or any official, professional or business man of the same place.

We Grow Our Plants in a New Place Each Season, rotating with clover and other crops of good soil that is still new and capable of producing well balanced, best grade plants-the kind we advertise.

We Maintain Our Grade by a careful selection of stock plants, and right method of propagation from year to year, that tend with such a soil to produce stock of the greatest health and vigor, striving for the ideal fruiting row and perfect fruit from any plants that may be left unsold.

Our Plants Are Fresh Dug as wanted, nicely trimmed, ready for planting, carefully re-sorted and tied in bunches of 25 ; roots washed in cold water if necessary to make them clean, and packed with live moss in new handle baskets lined with oil paper, or in light ventilated crates, in such a manner that we guarantee safe arrival in good condition by express or mail to all parts of the United States and Canada. Plants by freight at buyer's risk.

True to Name. We take great pains to have stock true to name and hold ourselves ready upon proper proof to refund money or replace any that prove untrue; but it is mutually agreed that we shall not be liable for a greater sum than the amount paid for such stock.

Our Prices Average Lower than can be found elsewhere, when quality of stock and guarantee conditions are considered. Our references for responsibility are ample. You take no risk whatever. See elsewhere a certificate of health from the State Inspector of Nurseries, L. R. Taft. Read our unsolicited testimonials. We invite investigation at all times.

The E. W. Potter Co., Leslie, Michigan.

May 8th, 1924.

Dear Sir: Received plants in excellent condition and I must say they are the healthiest looking plants I have ever received from any nursery.

Yours truly,

LOUIS J. KEMMER,

Manistee County, Michigan. 


\section{Gladiolus}

No doubt you will be surprised to see us listing something out of the ordinary in our strawberry plants catalog. However, the demand has caused us to list this extraordinary and most beautiful blooming plant produced. We have learned that the demand for these bulbs has far exceeded its supply and what we wish to do at the present time is to supply our customers with these bulbs at a reasonable price. If you are acquainted with these varieties you will find we have a very choice list. We expect in the future to add many other varieties that are recent introductions. We expect to test them all before offering them to the trade. We will use the same precaution in handling these bulbs that we have in handling our plants and they are all inspected by the State Inspector. I think you will find our prices very reasonable. If any other varieties are wanted other than those in our list, we might be of some help to you in obtaining them.

The Gladiolus is a delightful flower for the home garden. It grows from bulbs which increase in number from year to year. Plant them in shallow furrows any time in late April, May or June. Then keep the weeds down and the ground stirred occasionally. That is all there is to it, except the cutting of the great spikes of wonderful lily-like blooms which last ten days to two weeks in water. If the spikes are cut when the first two or three flowers have opened the entire stalk will open out after it has been put in water. They are very adaptable to send to friends at a distance, as they will arrive in excellent condition if just a little pains are taken when shipping. If you want to do this, the spikes should be cut when the first flower opens, and put in water in the cellar or cool place for two or three hours, so that they can take up a good drink, after which they will stand the journey of two or three days, and when placed in water will quickly respond and unfold their gorgeous petals.

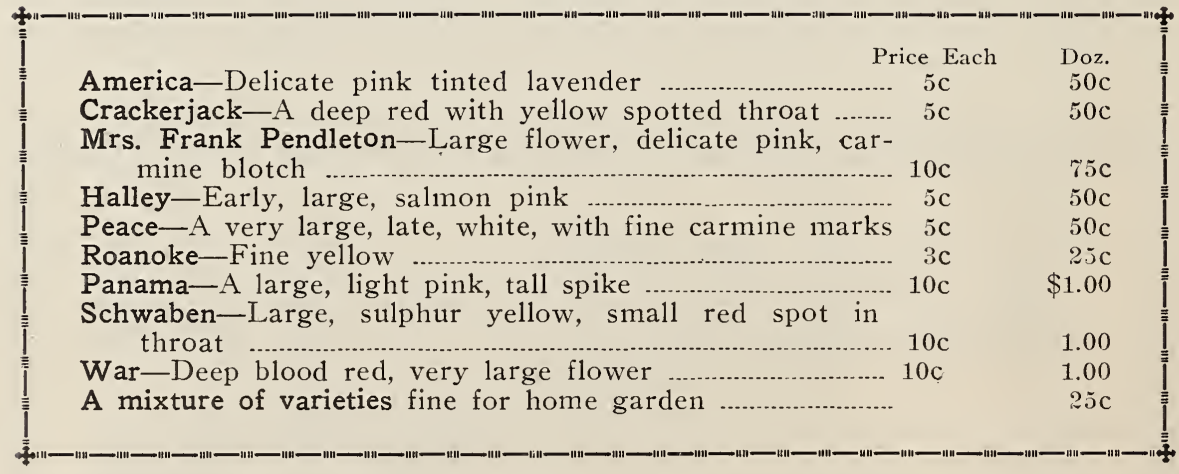




\section{Peck's Early Potatoes}

We have grown this extra early variety for many years and can strongly recommend them. They grow uniformly large and the yield is better than any early variety we know of. If you want a sort that will ripen early, and a heavy yielder of good quality, try them. They are pinkish in color and resemble the early Ohio.

No. 1 size, per bushel

\section{Yellow Dent Seed Corn}

This has been a very unfavorable season for the corn crop. The season was so late that the frost came before the corn had a chance to ripen. We hear of very little corn fit for seed. We were fortunate in getting our corn planted early and we have secured a limited amount of very fine seed corn. This corn has been selected and only the very best is offered. It is a heavy yielder of medium sized ears, handsome appearance of rich yellow color. It is an early variety and will mature in ninety days.

Peck, shelled ....\$1.50. Half bushel, shelled ....\$2.50. Bushel, shelled ....\$5.00.

The E. W. Potter Co., Leslie, Michigan.

February 13th, 1924.

Dear Sir: Plants received from you last spring did fine.

Yours,

E. M. HITCHCOCK,

Hampden County, Massachusetts.

The E. W. Potter Co., Leslie, Michigan.

February 15th, 1924.

Dear Sir: Please give me price on your Peck's Early Potatoes. I bought all my seed potatoes from you when you were with Flansburg and they were very nice.

Yours truly,

PETE WEYRAUCH,

Sangamon County, Illinois.

The E. W. Potter Co., Leslie, Michigan.

April 3rd, 1924.

Dear Sir: Enclosed please find money order for Twenty Dollars $(\$ 20.00)$ for the two No. 4 Garden Combination Offers, indicated on the order sheet. The plants I received from you a few years ago did very well and I hope these will be as well.

\section{Yours truly,}

RUSSELL PENHOLLOW, Chautauqua 'County, New York.

April 10th, 1924.

The E. W. Potter Co., Leslie, Michigan.

Dear Sir: Please send plants at once. I have ordered your plants before and like them fine.

Yours truly,

CASH HIATT,

Rockcastle County, Kentucky. 


\section{PRICE LIST -- Strawberries}

These prices are all F. O. B. Leslie, Michigan

500 at 1000 Rate.

Aroma
Abington
August Luther
Americus
Bubach
Buster
Billy Sunday
Brandywine
Bederwood
Charles 1st
Chesapeake
Clyde
Climax

50 at 100 Rate.

$100 \quad 250$

$\$ 0.60$

.60

.60

1.30

.65

1.00

.65

.65

.60

1.00

.65

.70

1.00

.60

1.00

.60

.60

.60

.60

1.30

1.00

.60

.60

.60

1.00

.70

.60

.65

.60

.60

.60

.65

.60

.70

1.00

.70

.65

1.00

.60
1.60

1.60
.60

.60
1.00

.60

.60

1.25

.60

.60

.60

.65

.65

1.00

.65
.50

1.60

1.35

3.25

1.35

1.35

1.35

1.35

1.50

4.00

1.35

1.35

1.20

1.35

1.50

1.50

1,000

$\$ 5.00$

5.00

5.00

1.35

3.00

1.50

5.50

1.50

1.50

1.35

5.50

5.00

ธ.50

1.50

6.00

5.00

1.35

$\overline{1.35}$

1.35

1.35

1.35

1.20

1.60

1.35

1.50

1.35

1.50

1.60

5.00

5.00

5.00

5.00

12.00

5.00

5.00

4.50

6.00

5.00

5.50

5.00

5.00

5.00

5.00

5.00

6.00

1.60

6.00

5.50

1.35

5.00

15.00

5.00

1.35

5.00

5.00

3.00

1.20

10.00

4.50

5.00

4.50

5.50

5.50

.15

.15

.25

.20

Write us for prices on 5,000 and 10,000 lots.

THE EARLY ORDER GETS THE VARIETIES WANTED 


\section{PLEASE, USE THIS ORDER SHEET \\ ORDER SHEET}

Name

P. O.

County

State.

R. R. Express Station

Sent by

Send by

Ship on or about

If we are sold out of anything ordered, may we substitute? If so, what?

(See note under plant price list)
$\$$

Please state whether in cash, stamps, money order, check or draft.

Date $192 \ldots$

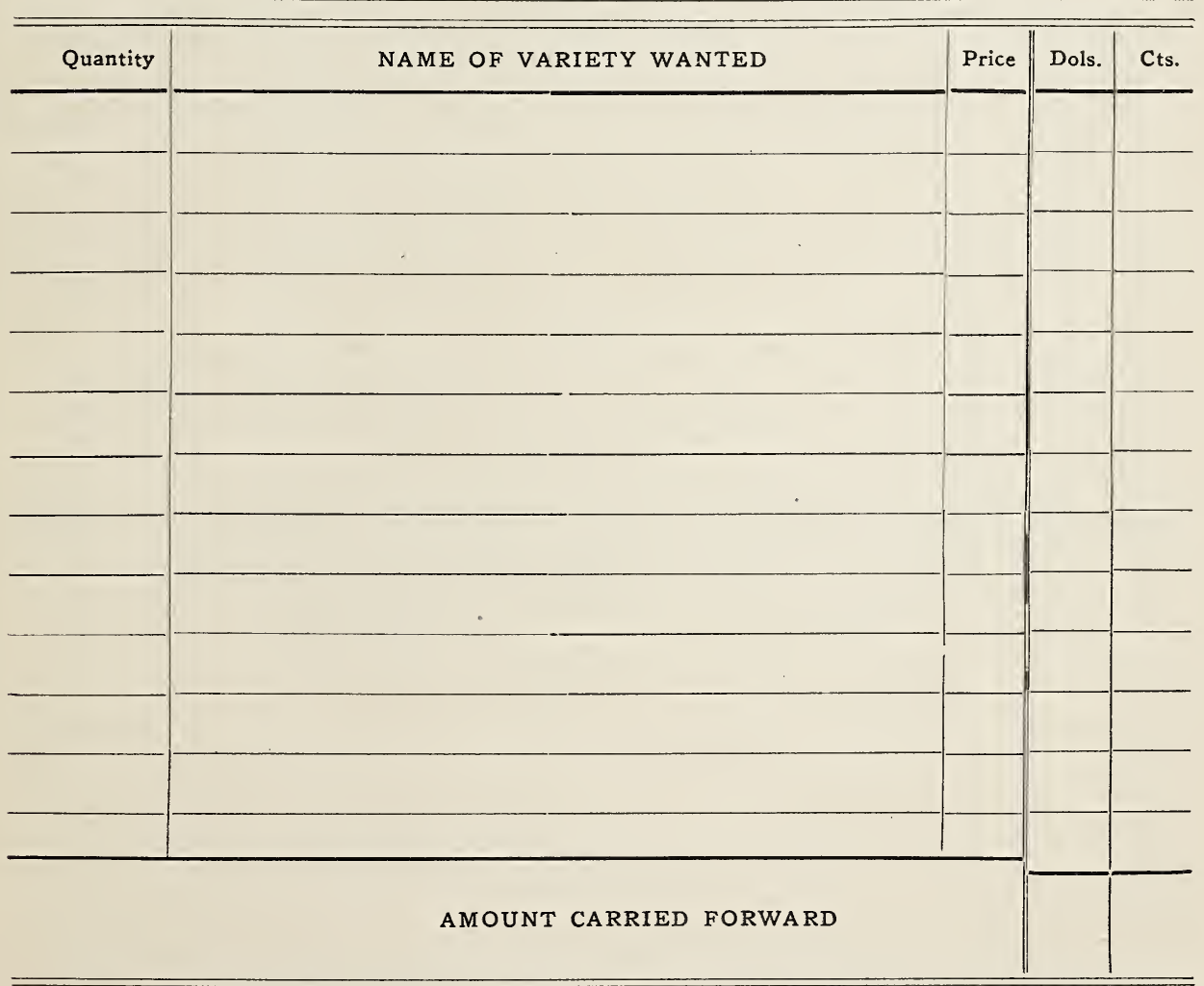


AMOUNT BROUGHT FORWARD

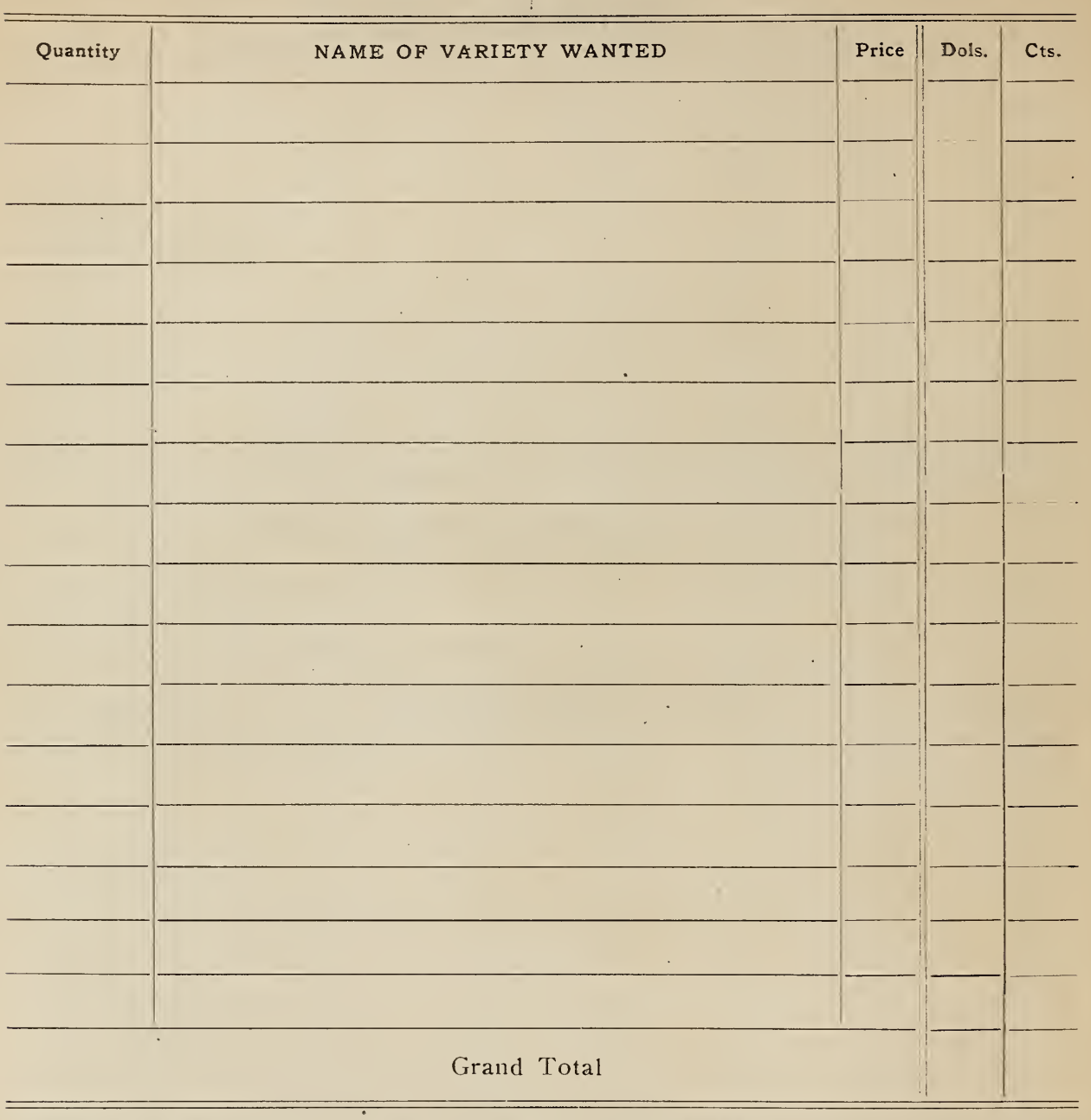

Please write below the names and postoffice addresses of such of your friends who would be likely to send away from home for fruit plants

\begin{tabular}{l|l|l|l|l|}
\hline NAME & Sostate \\
\hline & & & \\
\hline & & & \\
\hline
\end{tabular}




\section{Raspberries}

Any soil that will produce good field crop is suitable for raspberries. The red and black varieties have proven a very profitable crop for the past few years, and every fruit grower should plant a few.

We generally set.Black Caps about 3 or 4 feet apart in row, and rows 6 to 7 feet apart. The red varieties may be set 6 feet by 3 feet.

\section{Red Raspberries \\ CUTHBERT}

This is a valuable variety, well tested throughout the country. It is a rank, vigorous grower, making many plants, which should be kept cut back with the hoe or cultivator. It ripens mid-season and continues to very late. The quality is good. Dozen, 40c; $50, \$ 1.00 ; 1,000, \$ 12.50$.

\section{ST. REGIS}

This wonderful Red Raspberry pleased us again this season. It ripens about a week earlier than Cuthbert, not quite as large as Cuthbert but produces as many bushels per acre. It is a money maker. The new canes produce fruit in the fall. By express-dozen, 60c; $100, \$ 3.00 ; 500, \$ 15.00 ; 1,000, \$ 30.00$.

\section{Black Raspberries PLUM FARMER}

One of the new varieties of Black Caps. It has given great satisfaction and growers are enthusiastic over it. A vigorous grower and hardy. The fruit is large, like Cumberland, but a little earlier season. Per dozen, 40c; 50, $\$ 1.00 ; 100$, $\$ 2.00 ; 500, \$ 10.00 ; 1,000, \$ 20.00$.

\section{CUMBERLAND}

This is a valuable variety well tested throughout the country. It is very hardy and productive. The fruit is very handsome and is sure to bring a good price. Per dozen, 40c; $50, \$ 1.00 ; 100, \$ 2.00 ; 500, \$ 10.00 ; 1,000, \$ 20.00$.

\section{Blackberries}

The culture is about the same as the Raspberry. The canes should be pinched back when they reach the height of $31 / 2$ to 4 feet. They should be planted in rows 6 or 7 feet apart and 3 to 5 feet in the rows.

\section{ELDORADO}

- This is undoubtedly one of the best blackberries. Its large size and delicious quality puts it far in advance of some other varieties. It is very hardy and never winter kills in northern climate. The berries are large, jet black, borne in large clusters and ripen well together. Dozen, $40 \mathrm{c} ; 100, \$ 2.75 ; 1,000, \$ 25.00$.

The E. W. Potter Co., Leslie, Michigan.

$$
\text { May 12th, } 1924 .
$$

Dear Sir: Strawberry and Raspberry plants arrived O. K. and was well pleased with them. Hope I can give you a large order next year.

Yours truly,

JNO. KENSLER,

Washtenaw County, Michigan.

The E. IV. Potter Co., Leslie, Michigan.

May 19 th, 1924 .

Dear Sir: Very sorry you were all sold out of the Black Raspberry plants. We are strong for Potter's plants.

Yours truly,

MR. AND MRS. P. L. ZANDER,

Eaton County, Michigan. 


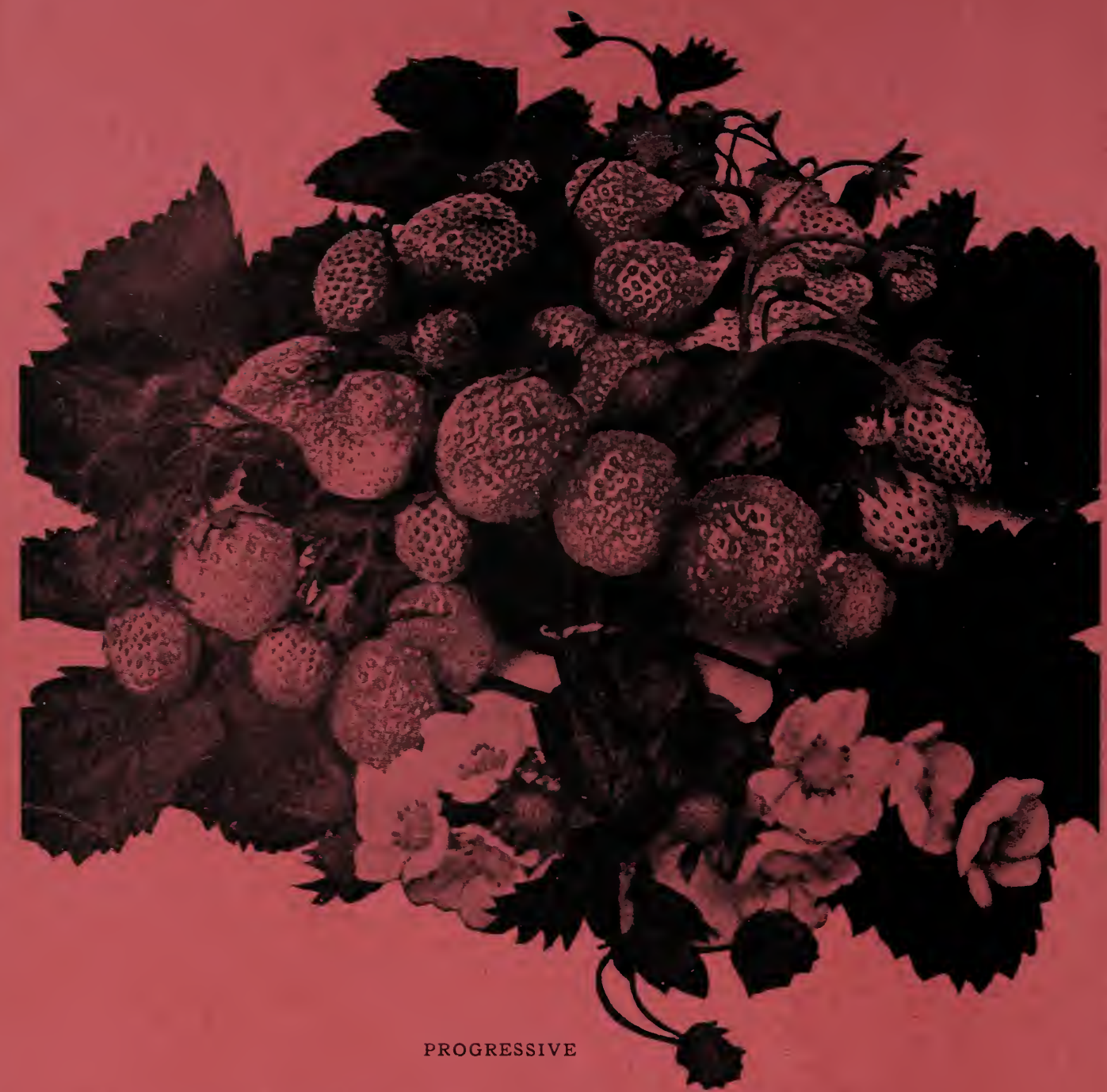

Order Progressize and have Shortcakes in September and October

\section{CERTIFICATE OF NURSERY}

INSPECTION

THIS IS TO CERTIFY. That I have examined the nursery stock and premises of The E. IV. Potter Co.. Leslie. Michigan. and find them apparently free from dangerous insects and dangerous contagious tree and plant disease.

This certificate to be void after July $31,1925$.

$$
\text { L. R. TAFT, }
$$

State Inspector of Nurseries and Orchards. Agricultural College, Michigan. July 22, 1924. 